\title{
PKM PENERAPAN TEKNOLOGI MOBILE DALAM MENINGKATKAN KEPUASAN MASYARAKAT KEPADA PENYEDIA JASA TRAVEL BERBASIS SMART CITY
}

\author{
Imelda \\ imelda@email.unikom.ac.id \\ Tatik Rohmawati \\ tatik.rohmawati@email.unikom.ac.id \\ Aprianti Putri Sujana \\ aprianti.putri.sujana@email.unikom.ac.id \\ Andri Sahata Sitanggang \\ andri.sahata@email.unikom.ac.id \\ UNIVERSITAS KOMPUTER INDONESIA
}

\begin{abstract}
ABSTRAK
Menciptakan inovasi teknologi dalam lingkungan masyarakat saat ini dibutuhkan untuk peningkatan kualitas jasa perusahaan. Teknologi tersebut berupa aplikasi mobile dikhususkan untuk pemesanan jasa travel Krakaline. Dengan adanya hal tersebut, maka kegiatan pengabdian ini adalah melakukan penerapan teknologi informasi berupa aplikasi. Kegiatan ini dilakukan pada 2 lingkungan, yaitu lingkungan perusahaaan yaitu Krakaline dan lingkungan masyarakat sebagai pengguna jasa travel krakaline tersebut. Penerapan teknologi ini menggunakan metode pendekatan dua arah, yaitu mengajak pihak perusahaan dan masyarakat untuk berdiskusi/berdialog, bersama-sama membuat solusi yang terbaik, dan tim melakukan evaluasi teknologi dan memperbaharui teknologi yang berjalan saat ini untuk digantikan dengan penerapan aplikasi mobile. Dengan adanya aplikasi ini maka akan mempermudah bagi perusahaan dan masyarakat dalam melakukan transaksi baik untuk pemesanan jasa travel, pembayaran dan laporan transaksi. Hasil kegiatan ini adalah dapat meningkatkan pengetahuan dan keterampilan kepada penggunaan teknologi khususnya penggunan aplikasi booking online.
\end{abstract}

Kata kunci: Teknologi, Aplikasi, Booking, Online.

\section{PENDAHULUAN}

\section{Latar belakang}

Transportasi adalah usaha manusia dalam kegiatannya melakukan perpindahan barang atau orang dari satu tempat ketempat lain. Transportasi yang baik akan selalu mengalami perkembangan dan kemajuan sesuai dengan teknologi yang berkembang (Utami, 2009), maka transportasi merupakan aset yang sangat penting dalam masyarakat Indonesia. Di dalam kehidupan sehari-hari masyarakat akan diperbantukan dalam memenuhi kebutuhannya, bayangkan jika transportasi tidak ada di Indonesia maka 
apa yang akan terjadi. Tentunya akan sangat menghambat roda kehidupan disemua aspek dan disegala bidang. Dengan adanya transportasi maka memberikan dampak dan pengaruh yang sangat besar untuk memajukan kehidupan khususnya untuk perekonomian suatu masyarakat.

Menurut Dinas Pendapatan daerah Provinsi Jawa Barat 2015 pada Gambar 1.

\begin{tabular}{|c|c|c|c|c|c|}
\hline & $\begin{array}{l}\text { Jenis Kendaraan } \\
\text { Vehicle Type }\end{array}$ & $\begin{array}{l}\text { Kota } \\
\text { Bandung I } \\
\text { Pajajaran }\end{array}$ & $\begin{array}{c}\text { Kota } \\
\text { Bandung II } \\
\text { Kawaluyaan }\end{array}$ & $\begin{array}{l}\text { Kota } \\
\text { Bandung } \\
\text { III Soeta }\end{array}$ & Jumlah \\
\hline & (1) & (2) & (3) & (4) & \\
\hline \multirow[t]{4}{*}{1} & $\begin{array}{l}\text { Sedan, Jeep, Station } \\
\text { Wagon }\end{array}$ & & & & \\
\hline & Pribadi & 112879 & 131563 & 113138 & 357580 \\
\hline & Dinas & 496 & 3205 & 343 & 4044 \\
\hline & Umum & 2961 & 3045 & 1743 & 7749 \\
\hline \multirow[t]{4}{*}{2} & Bus, Microbus & & & & \\
\hline & Pribadi & 832 & 1056 & 502 & 2390 \\
\hline & Dinas & 52 & 274 & 19 & 345 \\
\hline & Umum & 823 & 1642 & 861 & 3326 \\
\hline \multirow[t]{4}{*}{3} & Truck, Pick Up & & & & \\
\hline & Pribadi & 27774 & 20937 & 16326 & 65037 \\
\hline & Dinas & 116 & 1346 & 54 & 1516 \\
\hline & Umum & 2170 & 770 & 800 & 3740 \\
\hline \multirow[t]{4}{*}{4} & Alat Berat & & & & \\
\hline & Pribadi & & 3 & - & 3 \\
\hline & Dinas & & 4 & - & 4 \\
\hline & Umum & & - & - & \\
\hline \multirow[t]{4}{*}{5} & Sepeda Motor, Scooter & & & & \\
\hline & Pribadi & 432694 & 395754 & 329791 & 1158239 \\
\hline & Dinas & 942 & 10955 & 1152 & 13049 \\
\hline & Umum & & - & - & \\
\hline \multirow{4}{*}{6} & $\begin{array}{l}\text { Jumlah } \\
\text { Pribadi }\end{array}$ & 574179 & 549313 & 459757 & 1583249 \\
\hline & Dinas & 1606 & 15784 & 1568 & 18958 \\
\hline & Umum & 5954 & 5457 & 3404 & 14815 \\
\hline & Total KBM & 581739 & 570554 & 464729 & 1617022 \\
\hline
\end{tabular}

\section{Gambar 1 Potensi Kendaraan Bermotor di Bandung (BPS, 2016)}

Jasa transportasi pada saat ini adalah layanan jasa yang berkembang khususnya di kota Bandung. Hal ini terjadi dikarenakan semakin bervariasinya kebutuhan masyarakat akan transportasi, seperti tersedianya jasa diberbagai lokasi keberangkatan dan tujuan keberangkatan, dengan adanya hal ini mempermudah masyarakat dalam mendapatkan jasa ini. Maka sekarang bermunculan jasa transportasi melalui jasa travel. Travel adalah sebuah layanan jasa yang diberikan suatu perusahan untuk menyediakan transportasi dengan tujuan keberangkatan tertentu(Septavia, Gunadhi, \& Kurniawati, 2005). Berbagai jenis travel dibandung saling bersaing dalam memberikan pelayanan kepada masyarakat. Fasilitas pelayanan adalah salah satu kunci yang memberikan pengaruh terhadap penjualan suatu barang atau jasa yang dihasilkan oleh perusahaan. Pelayanan yang baik adalah harus memuaskan di mana di dalamnya terdapat unsur kecepatan, ketepatan, keramahan dan kenyamanan Salah satu faktor pendukung layanan transporasi antara lain (Utami, 2009):

1. Faktor kesadaran

Kesadaran menunjukkan suatu keadaan pada jiwa seseorang yang merupakan titik temu equilibrium dari berbagai pertimbangan sehingga diperoleh suatu kesadaran, ketenangan, ketetapan hati dan keseimbangan dalam jiwa bersangkutan (Utami, 2009).

\section{Faktor aturan}

Aturan merupakan perangkat penting dalam segala hal tindakan dan perbuatan orang. Makin maju dan majemuk suatu masyarakat, makin besar peraturan dan dapat dikatakan orang tidak dapat hidup layak dan tenang tanpa aturan (Utami, 2009).

\section{Faktor organisasi}

Organisasi pelayanan pada dasarnya tidak berbeda dengan organisasi pada umumnya, namun ada perbedaan sedikit dalam penerapannya, karena sasaran pelayanan ditunjukkan secara khusus kepada manusia yang mempunyai watak dan kehendak yang bermacam-macam (Utami, 2009).

Mengacu kepada pelayanan jasa, maka salah satu pelayanan yang bisa diberikan adalah kemudahan informasi dalam menggunakan jasa transportasi melalui media online baik menggunakan website ataupun aplikasi mobile. Kesuksesan aplikasi adalah memberikan informasi yang luas dan kemudahan dalam melakukan transaksi memberikan banyak keunggulan yang dirasakan oleh masyarakat. Menurut (Zakaria, 2008) keuntungan menggunakan aplikasi mobile adalah:

1. Menghemat waktu dan tenaga.

Dengan adanya hal ini, maka pengguna jasa transportasi tidak bersusah payah melakukan transaksi di lokasi travel tersebut. Pemesanan tersebut dapat tersedia 
secara online melalui fungsi-fungsi yang ada dalam aplikasi tersebut.

2. Informasi yang realtime dan up to date.

Memperoleh informasi secara up to date terpenuhi tanpa terhalang waktu dan tempat. Masyarakat dapat melakukan perubahan apa saja mengenai informasi yang berkenaan dengan transaksi dan berubah secara otomatis, contohnya untuk perubahan jadwal dan tujuan keberangkatan, ataupun pembatalan transaksi.

Tapi teknologi tersebut tidak didapatkan pada Krakaline Shuttle. Ada berbagai macam permasalahan yang dihadapi sehingga ini adalah tujuan dari tim pengabdian untuk memberikan solusi atas permasalahan yang dihadapi oleh pihak travel dan masyarakat.

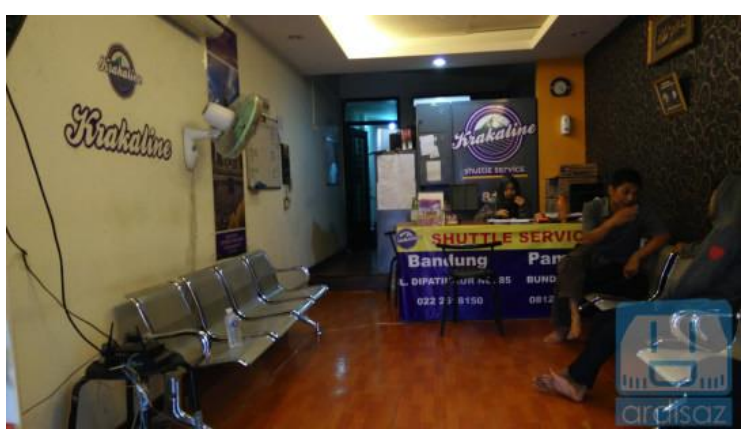

Gambar 2. Lokasi Pengabdian

Pada Gambar 2 menunjukkan jasa travel ini berada daerah bandung tepatnya di jalan dipatiukur Bandung, dimana kantor Krakaline adalah tempat pemesanannya, jadi jika masyarakat atau konsumen ingin menggunakan jasa travel, diharuskan datang langsung ketempat kantor pemesanannya. Hal ini ditandai dengan pencatatan tranksaksi yang meliputi pemesanan dan pembayaran jasa travel menggunakan pencatatan kedalam sebuh buku, dan tulisan kecil pada sebuah "note", maka berdasarkan dialog dan diskusi bersama dengan pihak travel dan masyarakat, dirumuskanlah masalah antara lain:

1. Fenomena yang terjadi pada saat ini adalah bahwa masyarakat hanya mengandalkan informasi yang diberikan pada saat datang langsung ke pihak travel, sehingga banyak sekali masyarakat yang kurang minat dengan travel ini. Informasi yang didapatkan melalui media telepon sering kali sulit dihubungi, sehingga masyarakat lebih memilih travel yang fasilitasnya mudah untuk didapatkan khususnya untuk informasi.

2. Minimnya penggunaan teknologi komputer dan internet mendukung untuk banyaknya permasalahan yang terjadi pada jasa travel ini.

3. Pembatalan jadwal keberangkatan yang tiba-tiba tidak dinformasikan kepada pihak konsumen menyebabkan masyarakat/konsumen enggan untuk kembali menggunakan jasa travel tersebut.

4. Permasalahan-permasalahan yang terjadi dalam masyarakat menyebabkan pihak travel mengalami penurunan pelayanan sehingga tidak dapat bersaing dengan travel lainnya yang sudah menggunakan teknologi sebagai alat bantu yang mempermudah pengolahan informasi dan fasilitas.

Maka langkah untuk memberikan solusi atas permasalahan yang terjadi dijelaskan melalui Gambar 3.

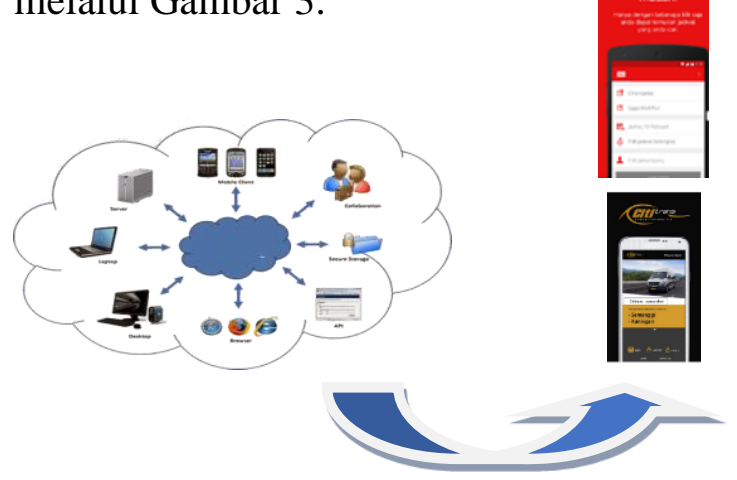

Gambar 3. Solusi Aplikasi

Salah satu cara yang dibentuk adalah dengan menerapkan sistem aplikasi mobile tiketing yang merupakan inovasi teknologi m-commerce dan mobile yang proses transaksi perdagangannya dibangun melalui perangkat mobile dengan menggunakan teknologi informasi. Tujuan kegiatan pengabdian ini, antara lain: 
1. Menyediakan kemudahan layanan jasa transportasi menggunakan mobile.

2. Meningkatkan pelayanan jasa transportasi kepada masyarakat pengguna jasa Krakaline Shuttle.

3. Memberikan jaminan informasi transportasi yang digunakan secara cepat dan akurat dengan menggunakan aplikasi mobile ticketing berbasis android.

4. Mengurangi traffic antrian khususnya pengguna jasa transportasi untuk waktu tertentu seperti hari raya, hari libur.

5. Melakukan pemerataan penggunakan teknologi mobile berbasis android untuk layanan jasa transportasi khususnya jasa travel di Bandung

Berdasarkan solusi yang ditawarkan maka tim pengabdian melakukan pemetaan untuk solusi dan target luaran dalam bentuk table 1 .

Table 1 Solusi dan Target Luaran

\begin{tabular}{|l|l|l|}
\hline No & \multicolumn{1}{|c|}{ Jenis Luaran } & $\begin{array}{l}\text { Indikator } \\
\text { Capaian }\end{array}$ \\
\hline 1 & $\begin{array}{l}\text { Publikasi ilmiah } \\
\text { dijurnal/prosiding }\end{array}$ & Ada \\
\hline 2 & $\begin{array}{l}\text { Publikasi Pada Media } \\
\text { Massa(cetak/elektronik }\end{array}$ & Ada \\
\hline 3 & $\begin{array}{l}\text { Peningkatan omzet } \\
\text { pada mitra yang } \\
\text { bergerak dalam bidang } \\
\text { ekonomi }\end{array}$ & Belum \\
\hline 4 & $\begin{array}{l}\text { Peningkatan kualitas } \\
\text { dan kuantitas produk }\end{array}$ & Ada \\
\hline 5 & $\begin{array}{l}\text { Peningkatan } \\
\text { pemahaman dan } \\
\text { keterampilan } \\
\text { masyarakat }\end{array}$ & Ada \\
\hline 6 & $\begin{array}{l}\text { Peningkatan } \\
\text { ketentraman/kesehatan } \\
\text { pada masyarakat(mitra } \\
\text { masyarakat umum) }\end{array}$ & Tidak ada \\
\hline 7 & $\begin{array}{l}\text { Jasa,model, rekayasa } \\
\text { social,system, Ada } \\
\text { produk/barang }\end{array}$ & $\begin{array}{l}\text { Hak kekayaan } \\
\text { intelektual }\end{array}$ \\
\hline $8 d a$ \\
\hline
\end{tabular}

\section{Lokasi Pengabdian}

Kegiatan ini diadakan di Krakaline Shuttle Bandung yang berlokasi di Jl. Dipati Ukur No.67, Lebakgede, Coblong, Kota Bandung, Jawa Barat 40132

\section{Jumlah Peserta}

Kegiatan pengabdian ini diikuti oleh pihak perusahaan dan masyarakat.

\section{METODE KEGIATAN}

1. Keterlibatan Pihak Pengguna Pihak Pengguna Aplikasi Mobile Ticketing berbasis $M$-Commerce.

Para Pengguna terlibat dalam menerapkan aplikasi dengan tujuan untuk mendukung teknologi yang bermanfaat bagi masyarakat. Hal ini dimaksudkan pula agar mempermudah masyarakat dalam menggunakan teknologi (Sitanggang, Wahyuni, Syafariani, \& Arianto, 2019). Pihak-pihak yang terlibat adalah :

a) Pihak Perusahaan Krakaline

Pihak yang akan mengikuti kegiatan pelatihan penerapan aplikasi mobile ticketing, sebagai salah satu mitra yang akan menguji aplikasi yang sudah dibuat.

b) Masyarakat/Konsumen

Pihak yang secara langsung menggunakan teknologi melalui pemakaian jasa travel Krakaline dengan aplikasi mobile ticketing.

c) Pengusul sebagai tim pengabdian Yang membuat aplikasi sesuai dengan kebutuhan pengguna.

d) Teknisi jaringan Yang akan mengatur jaringan yang mendukung aplikasi mobile ticketing.

e) Pembantu lapangan (terdiri dari 4 orang mahasiswa).

f) Membantu tim pengabdian, pihak perusahaan, dan masyarakat dalam menggunakan aplikasi mobile ticketing.

g) Programmer (Pembuat Aplikasi). Membuat aplikasi ticketing mobile yang akan diterapkan dimasyarakat dan Krakaline Shuttle. 
h) Bagian dokumentasi

Melakukan pendokumentasian dalam kegiatan-kegiatan dari awal pengabdian hingga akhir pengabdian.

\section{Metode Pelaksanaan}

Kegiatan ini menggunakan beberapa pendekatan aplikasi dan kebutuhan data. Berikut pendekatan aplikasi pada Gambar 4.

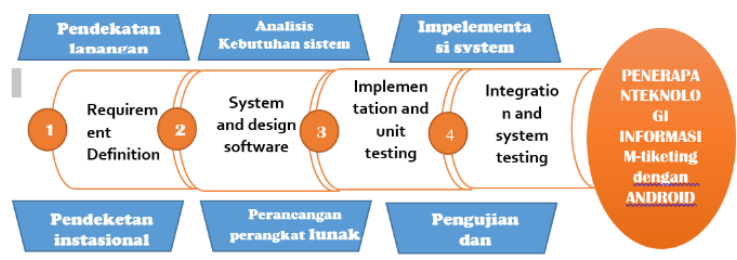

Gambar 4. Pendekatan Aplikasi (Sujana, Sitanggang, \& Pramono, 2018)

1. Pendekatan Lapangan, yang dilakukan guna memperoleh data dan informasi primer melalu observasi/survei lapangan, meliputi objek penelitian, data wilayah sekeloa, data transportasi, data jumlah transportasi, daerah pool dan tujuan keberangkatan.

2. Pendekatan Instansional yang dilakukan untuk memperoleh data dan informasi sekunder yang dilanjutkan dengan koordinasi dan konsultasi/wawancara serta pembahasan kepada pihak-pihak terkait.seperti pihak perusahaan dan masyarakat.

3. Pendekatan Kepustakaan yang dilakukan melalui kajian literatur (desk study) yang memuat ketentuan baik yang bersifat pemikiran/konsep terkait. Pada pendekatan ini akan dilakukan kajian sistem keseluruhan, mulai dari studi aplikasi mobile, studi mobile berbasis android dan studi mengenai aplikasi dalam membangun perangkat lunak itu sendiri.

4. Analisis Kebutuhan Sistem, mulai dari kebutuhan perangkat lunak (Penerapan M-Tiketing dengan teknologi E-Booking berbasis android), kebutuhan database dan kebutuhan hardware.

5. Perancangan Perangkat Lunak, meliputi dari pembuatan aplikasi mobile berbasis android yaitu terdiri dari perancangan interface, database, perancangan fungsifungsi dari aplikasi mobile, perancangan menu aplikasi.

6. Implementasi Sistem, melakukan pembangunan/coding perangkat lunak yang sebelumnya sudah dirancang. Mengimplementasikan kode-kode program, membangun database dan beberapa interface yang dibutuhkan.

7. Pengujian, melakukan pengujian perangkat lunak dengan menggunakan studi kasus yang telah ditentukan sebelumnya, diharapkan hasil pengujian sesuai dengan kebutuhan pengguna dan kebutuhan sistem secara keseluruhan.

8. Evaluasi, melakukan evaluasi terhadap hasil yang telah diperoleh pada tahap pengujian. Evaluasi ini tujuannya adalah untuk memastikan apakah Aplikasi Tiketing yang telah dibangun telah sesuai dengan kebutuhan yang telah didefinisikan di awal (kebutuhan pengguna).

Berdasarkan solusi atas permasalahan yang terjadi maka diperlukan pelatihan berupa

Maka berdasarkan solusi diatas dirancanglah sebuah pelatihan berupa (Sitanggang et al., 2019):

a) Pelatihan dan pembinaan penggunaan teknologi informasi pihak perusahaan dalam menggunakan aplikasi tiketing berbasis android kepada perusahaan Krakaline Shuttle.

b) Pelatihan dan pembinaan penggunaan aplikasi ticketing berbasis android kepada masyarakat Coblong.

c) Pelatihan kemampuan/keterampilan bagi pihak perusahaan dengan memamfaatkan teknologi informasi berupa komputer dan aplikasi tiketing berbasis android.

3. Pelaksanaan Pelatihan

Pelaksanaan pelatihan ini diberikan kepada 2 kelompok, yaitu kelompok masyarakat dan kelompok perusahaan 


\section{Denorapall apollkas]}

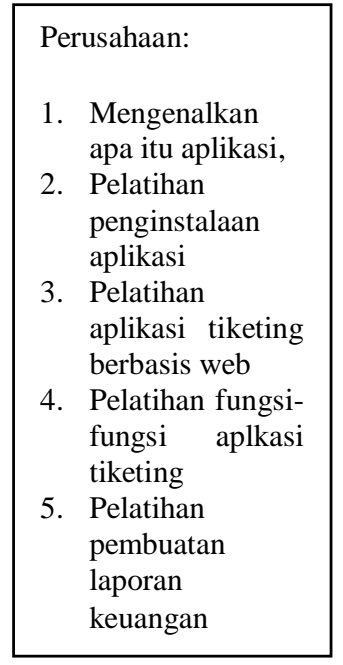

pengelolaan administrasi, dan bagaimana pihak perusahaan dalam memamfaatkan teknologi informasi berupa aplikasi. Kemudian dalam proses persiapan yang dilakukan adalah menentukan metode pelatihan sesuai dengan analisis awal, penyediaan software yang digunakan, penyiapan media yang dibutuhkan, penyiapan koneksi internet, dan penyiapan berbagai prosedur pelatihan dan pendampingan.

Pada tahap pelaksanaan kegiatan pengabdian yang dilakukan adalah proses instalasi software yang akan digunakan, proses pelatihan, dan simulasi aplikasi tiketing berbasis android. Pada tahapan keseluruhan yang dilakukan dilakukan pengendalian melalui pendampingan tim PKM pada Gambar 6 (Mulyani, R, \& M, 2018).

Gambar 5. Penerapan Aplikasi

Materi pelatihan yang diberikan antara lain:

a. Bagi perusahaan

1. Pelatihan pengelolaan laporan

2. Pelatihan pengelolaan pemesanan

3. Pelatihan pengelolaan jadwal

4. Pelatihan pengelolaan keluhan

5. Pelatihan pengelolaan sopir

6. Pelatihan pengelolan armada

7. Pelatihan pengelolaan fasilitas lainnya

b. Bagi masyarakat.

1. Pelatihan pengelolaan pemesanan tiket melalui aplikasi

2. Pelatihan pengelolaan pembayaran melalui aplikasi

3. Pelatihan pengelolaan promo yang diberikan

4. Pelatihan pengelolaan keluhan.

\section{Tahapan Kerja}

Tahapan kerja dari kegiatan pengabdian ini terdiri dari analisis awal, persiapan, pelaksanaan dan evaluasi. Dalam proses analisis awal yang dilakukan adalah untuk mengetahui proses transaksi pelayanan jada yang dilakukan oleh perusahaan Krakaline,

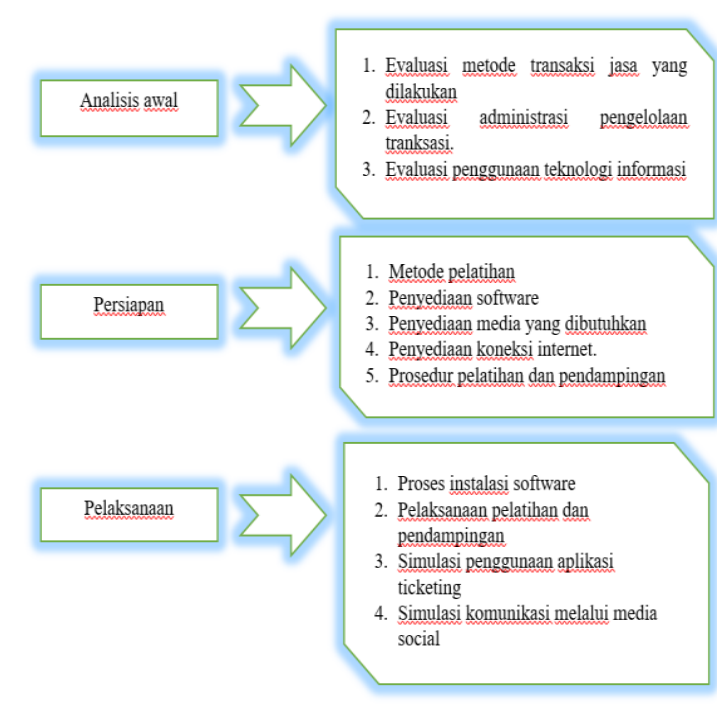

Gambar 6. Tahapan Kerja

\section{HASIL DAN LUARAN}

Kegiatan pengabdian kepada masyarakat dilakukan pada 2 kelompok, yaitu kelompok perusahaan dan kelompok masyarakat. Dimana kelompok perusahaan adalah para pegawai Krakaline Shuttle sedangkan kelompok masyarakat adalah para pengguna jasa travel Krakaline. Tahap pertama memberikan pelatihan kepada pihak perusahaan dan tahap kedua 
memberikan pelatihan kepada kelompok masyarakat (Sitanggang et al., 2019).

1. Tahap Pertama pelatihan aplikasi tiketing berbasis android kepada perusahaan.

Kegiatan ini dilakukan dengan cara melakukan observasi pada objek pengabdian, kemudian melakukan diskusi/dialogi mengenai system yang sedang berjalan saat ini, dan apa yang menjadi kekurangannya. Data tersebut dibutuhkan untuk menjadi bahan kajian pada saat akan melakukan penerapan aplikasi tiketing berbasis android (Sujana, Sitanggang, \& Maseleno, 2018). Dengan adanya kegiatan evaluasi pada sistem yang berjalan memberikan gambaran fungsi yang dibuat oleh tim pengabdian.

2. Tahap kedua pelatihan ticketing berbasis android kepada masyarakat.

Pengumpulan data merupakan syarat awal untuk

Dilakukan pada masyarakat yang menggunakan jasa travel Krakaline. Hal ini ditujukan agar masyarakat mengetahui bahwa adakan ada peningkatkan kualitas pelayanan perusahaan melalui penerapan aplikasi tiketing berbasis android. Pengumpulan data dimaksudkan agar kebutuhankebutuhan dapat digenapi dengan aplikasi tersebut. Pendekatan yang dilakukan yaitu dengan melakukan survey ke lokasi dimana terdapat sejumlah masyarakat yang sedang melakukan pemesanan travel, kemudian diarahkan melalui proses diskusi dan dialog per individu, kemudian tim pengabdian menuliskannya kedalam catatan evaluasi. Catatan ini yang akan menjadi dasar dalam penerapan fungsifungsi aplikasi tiketing berbasis android. Setelah aplikasi tersebut sudah siap pakai maka pelatihan aplikasi pun dilakukan dari awal register, pemesanan, pembayaran hingga mendapatkan tiket secara online dari travel Krakaline.

Dari hasil pelatihan yang dilakukan, maka seharusnya ada perubahan pada 2 kelompok tersebut. Perubahan tersebut ditandai dengan hal-hal berikut:

a. Perubahan metode transaksi yang dilakukan dari pemesanan, pembayaran, pembuatan tiket, dan pembuatan laporan dari konvensional secara bertahap menggunakan aplikasi ticketing berbasis android baik pihak travel dan masyarakat sebagai konsumen.

b. Peningkatan kualitas/wawasan para masyarakat baik pihak travel dan konsumen dalam memamfaatkan teknologi informasi sebagai alat pendukung kebutuhan.

c. Meningkatnya kemampuan para masyarakat dalam menerapkan teknologi informasi berupa aplikasi.

d. Meningkatnya jumlah konsumen yang menggunakan jasa travel Krakaline.

Setelah kegiatan pelaksanaan selesai dilaksanakan rencana berikutnya adalah mengawasi dan memantau apakah program pelatihan yang sudah diberikan berlangsung dengan dengan baik.

\section{KESIMPULAN}

Kesimpulan

Kegiatan pengabdian yang dilakukan diterapkan ke dalam 2 kelompok, yaitu kelompok masyarakat sebagai konsumen dan kelompok perusahaan. Tujuan pertama yang diberikan kepada perusahaan adalah bahwa dengan adanya teknologi berupa aplikasi menjadi salah satu penolong dalam meningkatkan pelayanan/layanan jasa kepada masyarakat dan mempermudah administrasi pengelolaan transasksi yang dilakukan dalam travel tersebut. Sedangkan untuk masyarakat adanya pengetahuan bahwa jasa yang sering digunakan sudah menggunakan aplikasi sebagai alat dalam transaksi, dan membantu masyarakat dalam menggunakan aplikasi yang akan diterapkan. 
Saran

1. Bagi pihak perusahaan

Adanya perubahan pola pikir yang diberikan terhadap teknologi informasi yang berkembang saat ini, bahwa teknologi informasi mempunyai banyak kelebihan yang dapat membantu dan memberi nilai tambah pada proses meningkatkan pelayanan kepada masyarakat sehingga kegiatan transaksi yang sudah dilakukan juga dapat berkesinambungan dan menciptakan inovasi lain dengan hadirnya aplikasi tiketing dalam artian kegiatan ini prosesnya berlanjut.

2. Bagi para masyarakat pengguna jasa travel Krakaline.

Adanya kata sepakat dalam penerimaan teknologi dalam masyarakat berupa aplikasi. Masyarakat dapat mengikuti era perkembangan teknologi dan bukan menjadikan teknologi musuh dalam masyarakat. Akan tetapi, memberikan dampak perubahan yang signifikan dalam meningkatkan solusi dalam memenuhi kebutuhan hidup.

\section{KESIMPULAN}

Artikel ini merupakan kegiatan pengabdian yang didanai dari Direktorat Riset dan Pengabdian kepada Masyarakat Direktorat Jenderal Penguatan Riset dan Pengembangan Kementerian Riset, Teknologi dan Pendidikan Tinggi dengan nomor kontrak 040/SP/LPPM/UNIKOM/III/2019 tanggal 3 Maret 2019. Juga merupakan partisipasi dan kerjasama dari pihak travel Krakaline dan tim pengabdian, yaitu dosen dan mahasiswa.

\section{DAFTAR PUSTAKA}

BPS. (2016). Kota Bandung Dalam Angka 2016. Bandungkota.Bps.Go.Id. Retrieved from https://bandungkota.bps.go.id/publica tion/2016/07/15/e1f27d4d9f7cadf8fc 33a97a/kota-bandung-dalam-angka2016.html
Mulyani, E. L., R, L. R., \& M, A. N. (2018). Smp It Daarussalaam Tasikmalaya. 1(1), 115-123.

Septavia, I., Gunadhi, R. E., \& Kurniawati, R. (2005). Sistem Informasi Penyewaan Mobil Berbasis Web. 1-8. Sitanggang, A. S., Wahyuni, W., Syafariani, R. F., \& Arianto, A. (2019). Penerapan Aplikasi Scout Learning Berbasis Multimedia dalam Meningkatkan Pengembangan Inovasi Minat Dan Bakat Ekstrakurikuler Bagi Sekolah Dasar Negeri 127 Sekeloa Bandung. Jurnal Pengabdian Kepada Masyarakat, $\quad 9(1), \quad 21$. https://doi.org/10.30999/jpkm.v9i1.5 62

Sujana, A. P., Sitanggang, A. S., \& Maseleno, A. (2018). Application of E-transport through android-based tiketing applications. Journal of Advanced Research in Dynamical and Control Systems, 10(13), 1786-1797.

Sujana, A. P., Sitanggang, A. S., \& Pramono, E. Y. (2018). PEMODELAN DALAM PERANCANGAN APLIKASI MOBILE TIKETING pada ETRANSPORT. Jurnal Ilmiah Nasional Bidang Teknik, 6(3), 69-76.

Utami, S. S. (2009). Analisis Faktor-Faktor Yang Mempengaruhi Kepuasan Konsumen Dalam Mempergunakan Jasa Transportasi Pt. Solo Central Taxi Di Surakarta. Jurnal Ekonomi Dan Kewirausahaan, 9(1), 33-44. https://doi.org/10.1017/CBO9781107 415324.004

Zakaria, T. M. (2008). Aplikasi Presensi via PDA dengan Konektivitas Melalui Jaringan WiFi. 67-83. 